\section{Disease spread leads Britain to pull plug on trial badger cull}

\section{Jim Giles, London}

A strategy to control tuberculosis (TB) in cattle by killing thousands of badgers a year seems to do more harm than good, according to the initial results of a nationwide study in Britain.

Badgers carry the bacterium that causes TB in cows, and are thought to be an important reservoir for the disease. In an attempt to control bovine $\mathrm{TB}$, the British government has overseen the culling of more than 20,000 badgers since 1975 in areas where herds are found to be infected - a strategy known as 'reactive culling'. This policy was put on hold in 1998 so that a study could assess the effectiveness of the method.

That study, led by John Bourne, a retired veterinarian formerly at the University of Reading, compared reactive culling with two other methods: no culling and 'proactive culling', in which badger numbers are reduced across entire trial areas regardless of the incidence of TB. The study involved 30 regions of England, each around $100 \mathrm{~km}^{2}$ in size, and was planned to run until 2005.

But Bourne's team decided last month to notify the government of the trial's initial results, as the number of infected herds in reactive-culling areas is now $27 \%$ higher than in regions without culls. The study does not reveal the cause of the increase, but researchers think that the culling may have prompted badgers to move between territories, increasing the spread of the disease. More results are required before they can judge whether the proactive strategy is more, or less, effective.

Ben Bradshaw, Britain's minister for nature conservation and fisheries, announced on 4 November that reactive culling will no longer be used in the trial. The results are disappointing for some, says Bradshaw, as reactive culling resulted in the death of fewer badgers than the proactive culling used in the trial. If effective, it could have been a compromise between farmers, who want to protect their cattle, and animal-welfare groups who oppose culling. "The reactive option would have been one of the most attractive policies for many people," he says.

Stephen Harris, an expert on TB and badgers at the University of Bristol, notes that proactive culling can be altered to have a lesser effect on badger populations and the environment. But in the end, he notes, "the only long term solution to the problem is to develop a cattle vaccine".

\title{
Florida welcomes Scripps as critics predict big-money fiop
}

Rex Dalton, San Diego

Florida governor Jeb Bush this week signed legislation that will help to pump $\$ 570$ million into bringing the Scripps Research Institute to the 'sunshine state'. But critics are already asking if the deal will attract the research jobs and biotechnology companies that its proponents claim.

The initiative to create Scripps Florida at Palm Beach has been spearheaded by Bush brother of President George Bush. Last month, he called a special session of the state legislature to put $\$ 310$ million into the deal, to pay for operations as the new institute builds up to house a projected 545 researchers after seven years.

On 23 October, the legislature approved the request, which includes another $\$ 60$ million in projected investment income from money being put aside now to fund operations. Palm Beach County will also pay $\$ 200$ million to build a huge lab complex for the institute. Bush has said the deal could bring up to 500 new firms and 44,000 jobs to Florida.

But sceptical Florida law-makers and economists say that this greatly overstates the benefits of the deal with Scripps, a non-profit organization whose only facility is in La Jolla, California. They also point to unanswered questions about the possible role of the Swiss drug firm Novartis in Scripps Florida's future.

Novartis and Scripps have a contract that says the pharmaceutical firm has first rights to select for product development up to $47 \%$ of ideas from the research institute at $\mathrm{La}$ Jolla. Novartis is paying Scripps \$20 million a year under this pact, which created considerable controversy when it was signed in 1994 by Scripps and the Swiss-based drug company Sandoz — since incorporated into Novartis. Critics of the deal said that Scripps,

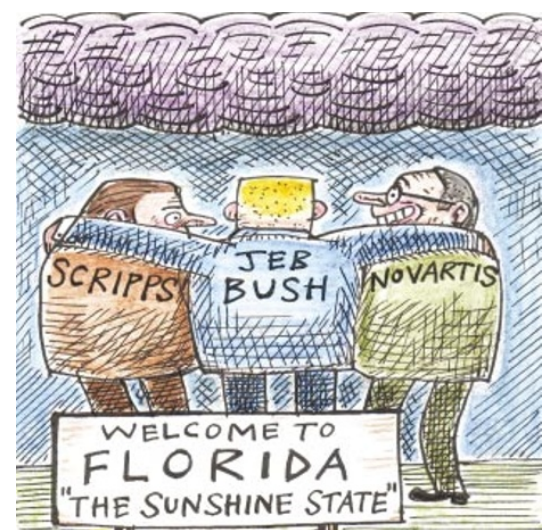

which gets $85 \%$ of its income from the National Institutes of Health, should not have allocated such broad product-development rights to one company.

Neither Novartis nor Scripps will say whether the Florida facility will be covered by the contractual agreement, which expires in December 2006. A Scripps spokesman says that the concept of Novartis selecting technology developed at Scripps Florida "is under discussion". Novartis officials refused repeated requests for comment.

In Florida, Jill Bratina, a spokeswoman for Bush, says that the existing Novartis-Scripps contract won't cover Scripps Florida. But she also adds that the governor's office is in discussion with Novartis and Novartis-funded researchers in La Jolla about possible future involvement in Scripps Florida.

If a renewed Novartis contract with Scripps did cover the Florida facility, it could have a major impact on the number of companies and biotechnology jobs that would spin off from it, critics say. Novartis would get automatic access to the most promising ideas for commercial development, they note.

Dan Gelber, a Democrat state representative for Miami Beach, who voted against the Scripps package in the legislature, says that most of his colleagues were unaware of such criticisms. "There was no deep thought put into this," he says. "The legislature didn't do the due diligence the taxpayers would hope for; it was the equivalent of buying a used car."

Gelber says independent experts estimate that the deal will create only 16,000 jobs over 15 years. And Joseph Cortright, an economist in Portland, Oregon, who specializes in the impact of biotechnology on regional development, calls the estimate of 500 new firms "ludicrous". Bratina counters that the governor's economic forecasts are solidly based on "conservative" estimates. 